\title{
Free Radicals as a Double-Edged Sword: The Cancer Preventive and Therapeutic Roles of Curcumin
}

\author{
Nehal Gupta ${ }^{1}{ }^{(}$, Kshitij Verma $^{2}{ }^{\circledR}$, Sarath Nalla ${ }^{3}$, Alok Kulshreshtha ${ }^{3}$, Rajiv Lall ${ }^{3}$ and \\ Sahdeo Prasad ${ }^{3, *}$ \\ 1 Department of Medicine, University of California San Francisco, 1600 Divisadero Street, \\ San Francisco, CA 94115, USA; nehal.gupta@ucsf.edu \\ 2 Discovery Chemistry, Genentech, Inc., 1 DNA Way, South San Francisco, CA 94080, USA; \\ verma.kshitij@gene.com \\ 3 Noble Pharma, LLC, 4602 Domain Drive, Menomonie, WI 54751, USA; sarathn@noblepharmallc.com (S.N.); \\ Alokk@noblepharmallc.com (A.K.); lallr123@yahoo.com (R.L.) \\ * Correspondence: spbiotech@gmail.com or sahdeop@noblepharmallc.com; \\ Tel.: +1-715-231-1234; Fax: +1-715-231-1235
}

Academic Editor: Alejandro Samhan-Arias

Received: 19 October 2020; Accepted: 15 November 2020; Published: 18 November 2020

\begin{abstract}
Free radicals, generally composed of reactive oxygen species (ROS) and reactive nitrogen species (RNS), are generated in the body by various endogenous and exogenous systems. The overproduction of free radicals is known to cause several chronic diseases including cancer. However, increased production of free radicals by chemotherapeutic drugs is also associated with apoptosis in cancer cells, indicating the dual nature of free radicals. Among various natural compounds, curcumin manifests as an antioxidant in normal cells that helps in the prevention of carcinogenesis. It also acts as a prooxidant in cancer cells and is associated with inducing apoptosis. Curcumin quenches free radicals, induces antioxidant enzymes (catalase, superoxide dismutase, glutathione peroxidase), and upregulates antioxidative protein markers-Nrf2 and HO-1 that lead to the suppression of cellular oxidative stress. In cancer cells, curcumin aggressively increases ROS that results in DNA damage and subsequently cancer cell death. It also sensitizes drug-resistant cancer cells and increases the anticancer effects of chemotherapeutic drugs. Thus, curcumin shows beneficial effects in prevention, treatment and chemosensitization of cancer cells. In this review, we will discuss the dual role of free radicals as well as the chemopreventive and chemotherapeutic effects of curcumin and its analogues against cancer.
\end{abstract}

Keywords: free radicals; ROS; cancer; curcumin; chemoprevention; therapy

\section{Introduction}

Free radicals are generally reactive oxygen species (ROS) and reactive nitrogen species (RNS), which are capable of independent existence. ROS and RNS can broadly be categorized into two groups-radicals and non-radicals. Superoxide $\left(\mathrm{O}_{2}^{-\bullet}\right)$, oxygen radical $\left(\mathrm{O}_{2}{ }^{\bullet \bullet}\right)$, hydroxyl $\left(\mathrm{OH}^{\bullet}\right)$, alkoxyradical $\left(\mathrm{RO}^{\bullet}\right)$, peroxyl radical $\left(\mathrm{ROO}^{\bullet}\right)$, nitric oxide $\left(\mathrm{NO}^{\bullet}\right)$ and nitrogen dioxide $\left(\mathrm{NO}_{2}{ }^{\bullet}\right)$ are various examples of radical species [1]. The non-radical species are comprised of hydrogen peroxide $\left(\mathrm{H}_{2} \mathrm{O}_{2}\right)$, hypochlorous acid $(\mathrm{HOCl})$, hypobromous acid $(\mathrm{HOBr})$, ozone $\left(\mathrm{O}_{3}\right)$, singlet oxygen $\left({ }^{1} \mathrm{O}_{2}\right)$, nitrous acid $\left(\mathrm{HNO}_{2}\right)$, nitrosyl cation $\left(\mathrm{NO}^{+}\right)$, nitroxyl anion $\left(\mathrm{NO}^{-}\right)$, dinitrogen trioxide $\left(\mathrm{N}_{2} \mathrm{O}_{3}\right)$, dinitrogen tetraoxide $\left(\mathrm{N}_{2} \mathrm{O}_{4}\right)$, nitronium cation $\left(\mathrm{NO}_{2}{ }^{+}\right)$, organic peroxides $(\mathrm{ROOH})$, aldehydes (HCOR) and peroxynitrite $(\mathrm{ONOOH})$. Radical species are comparatively highly reactive, due to the presence of an unpaired electron that imparts a high degree of electrophilicity. These free radicals act as oxidants or reductants by either donating an electron to or accepting an electron from other reactive molecules [2]. 
Free radicals are generated in the body by various endogenous and exogenous systems including pathological states and exposure to different physiochemical conditions. The formation of free radicals in the body is a continuous process through the enzymatic and non-enzymatic reactions. Mitochondria, peroxisomes, and phagocytic organelles participate in the enzymatic production of free radicals while non-enzymatic free radicals are produced by ionizing radiation and non-enzymatic reactions of oxygen with organic compounds [3]. Accumulated evidences suggest that free radicals cause progressive adverse effects in the body by increasing oxidative stress. Although the body has an antioxidant defense mechanism to balance the redox system, excessive production of ROS and RNS results in oxidative and nitrosative stress respectively. This chronic oxidative or nitrosative stress manifests in the form of a number of diseases including cancer. This is evident by a notion that the overproduction of free radicals has a close relation with increased incidences of cancer. It has also been found that a higher consumption of fats and oils leads to the increased production of free radicals correlated with the increased death rate from different types of cancer [4].

To combat the detrimental effects of free radical species ROS and RNS, a system of antioxidant defense is expressed in all living cells. The antioxidant system can be classified in multiple ways. It may be based on the source as exogenous (derived from dietary food intake) or endogenous (produced in the body), solubility in water (e.g., vitamin C) or lipids (e.g., vitamin E), or the size and nature of the antioxidant molecule, i.e., enzymatic (e.g., catalase) or non-enzymatic (e.g., flavonoids). Studies have shown that antioxidants reduce the occurrence of carcinogenesis. It has been observed that the consumption of fruits and vegetables, rich in antioxidants, in daily diet causes a reduction in the risk for cancer incidence [5]. In contrast, several studies have also shown that antioxidant from dietary supplements such as $\beta$-carotene and retinol promote tumor growth and metastasis in cancer patients [6-8]. However, various anticancer drugs kill cancer cells by producing free radicals [9]. Thus, these studies indicate that free radicals serve a dual purpose-inducing carcinogenesis and imparting in cancer cell death.

\section{Free Radicals as a Double Edge Sword}

Reactive oxygen species (ROS), produced either exogenously (e.g., radiation, chemicals, hyperoxia) or endogenously (normal cellular metabolism), are related to a wide variety of human disorders. Excessive ROS causes damage to proteins, DNA, and RNA leading to genetic alterations in cells. On the other hand, low levels of ROS are essential for various biological functions, including cell survival, cell growth, proliferation and differentiation, and immune response [10]. Lethal production of ROS by certain agents also causes death of cancer cells. These observations indicate the dual role of ROS in terms of cancer promoting and cancer suppressing activity. It is evident that ROS participates simultaneously in both the Ras-Raf-MEK1/2-ERK1/2 oncogenic signaling and the p38 mitogen-activated protein kinases (p38MAPK) tumor suppressing pathways [11]. Thus, depending on the cell type, ROS may function as cytoprotective or oncogenic.

\subsection{Carcinogenesis}

The high accumulation of ROS and/or low level of antioxidants in cells causes an imbalance in redox status, which is known as oxidative stress. Oxidative stress is implicated in a variety of pathologies including cancer. ROS are short-lived and highly electrophilic molecules generated by the partial reduction of oxygen to form superoxide $\left(\mathrm{O}_{2}^{-\bullet}\right)$, hydrogen peroxide $\left(\mathrm{H}_{2} \mathrm{O}_{2}\right)$, and hydroxyl radical $\left(\mathrm{HO}^{\bullet}\right)$ as well as secondary metabolites including lipid peroxides, peroxynitrite $\left(\mathrm{ONOO}^{-}\right)$, and hypochlorous acid $(\mathrm{HOCl})$. Because of their high reactivity, they cause damage to the macromolecules and disrupt biochemical function [12]. 
It has been known that ROS causes DNA strand breaks and oxidative damage to the nucleotides, subsequently resulting in mutagenesis and eventually cancer. The susceptible target of ROS in DNA is guanine that causes $\mathrm{G} \rightarrow \mathrm{T}$ transversions [13]. Additionally, ROS can also cause mutations by oxidative damage to a range of target sites in genetic materials including purines and pyrimidines, alkali labile sites, single strand breaks and disruption of DNA repair processes, leading to genetic instability [14,15]. ROS-induced carcinogenesis is supported by a study describing that elevated levels of ROS leads to modification of nucleobases in cancerous and precancerous tissues [16]. The initiation of cancer in humans caused by ROS is further supported by the presence of oxidative DNA modifications in cancer tissues [17]. Oxidative DNA damage leading to the development of breast cancer has also been reported. For instance, in inflammatory breast cancer, an increase in DNA base damage and 8-oxo-dG adducts leads to malignant cancer progression [18]. The role of oxidative stress in the development of hepatocellular carcinoma has also been reported, since ROS caused accumulation of 8-OHdG by oxidative DNA damage in the cells and further development of hepatocellular carcinoma [19]. The association of oxidative DNA damage and carcinogenesis have been found in a variety of other cancers. However, a comparative measurement of distinctively modified DNA bases in tumor tissue and their respective normal tissues is required to provide further insights into the involvement of ROS in carcinogenesis.

ROS also induces modifications of redox-sensitive amino acid residues in regulatory proteins including cysteine oxidation. Such modifications can modulate the regulatory effects of proteins and enzymes. The regulatory proteins such as kinases (MAPK and PI3K/Akt), transcription factors (Nrf2, AP-1, NF- $\mathrm{B}$, STAT3, and p53), components of ubiquitin/proteasome system and autophagy/lysosomal protein degradation systems, molecular chaperones, and cytoskeletal proteins are susceptible to altered physiological function by ROS [20]. These modifications in the regulatory proteins of non-cancerous cells dysregulate cellular homeostasis and as a consequence lead to initiation of carcinogenesis. Stimulation of these signaling pathways by ROS is also found to be involved in proliferation, migration, and invasion of human breast, liver, prostate, lung, skin, pancreatic, and many other cancer cells. Lipids are the other cellular target of ROS. ROS reacts with polyunsaturated or polydesaturated fatty acids to initiate lipid peroxidation [21]. The peroxidation of lipids generate numerous genotoxic molecules such as malondialdehyde, 2-alkenals and 4-hydroxy-2-alkenals [22]. ROS-induced lipid peroxidation may result in alteration of membrane structure, disruption in membrane permeability and interruption in immune system recognition, which cumulatively promotes cancer initiation and progression. The involvement of lipid peroxidation in carcinogenesis was made evident by the presence of thiobarbituric acid-reactive substances (a byproduct of lipid peroxidation) in the serum of patients with colorectal cancer [23].

\subsection{Therapeutic}

Cancer cells have a hypermetabolism that produces a large amount of ROS compared to normal cells. At the same time, cancer cells have marked antioxidant capacity that help in maintaining the redox balance. Recently, anticancer therapies that induce oxidative stress by increasing ROS and/or inhibiting antioxidant level have received great attention [24]. The increased ROS disrupts redox homeostasis and causes damage to the cancer cells and ultimately cell death. Numerous anticancer drugs utilize the principle of oxidative stress-induced chemotherapy.

Since cancer cells possess comparatively high ROS levels, these cells have a higher sensitivity towards increased prooxidant and decreased antioxidant levels [25,26]. This increased sensitivity to prooxidants induces cancer cell death using the process of apoptosis, necroptosis, and autophagy [27], which mediates either by direct induction of ROS generation and/or suppression of antioxidant levels [28]. Some anticancer drugs induce ROS generation and cause cancer cell death. For example, motexafin gadolinium, an electron acceptor, suppresses the irradiation-induced DNA repair and increases the effect of radiotherapy in many cancers [29-31]. Anthracycline-based anticancer drugs-such as doxorubicin-also accumulate hydroxyl radicals and cause the death of cancer cells [32]. 
Another drug, 2-methoxyestradiol, induces mitochondrial production of hydrogen peroxide [33] and subsequently activates c-Jun N-terminal kinase (JNK), resulting in initiation of apoptosis [34,35]; additionally, it can also potentiate the therapeutic action of other anticancer agents [36,37]

Besides these, several natural compounds also exhibit anticancer effects by inducing ROS. Resveratrol, a dietary product present in grapes, vegetables and berries, has been shown to exert an anti-cancer effects on melanoma cells through the induction of ROS. It has also been shown to induce ROS-p38-p53 pathway by increasing the gene expression of phosphorylated p38 MAPK and activating the p53 and ER stress pathway [38]. Ursolic acid, another natural compound, has been shown to induce apoptosis and enhance oxaliplatin-induced inhibition of colorectal cancer cell proliferation in both in vitro and in xenograft nude mouse models. The enhanced anti-proliferative effect of ursolic acid was found to be correlated with increased ROS production and decreased expression of drug resistance genes [39]. A combination of gambogic acid, a natural compound derived from the gamboge, (Garcinia species), also caused synergistic reduction of cell viability in SKOV-3 cells with doxorubicin and this effect was found to be correlated with increased cellular ROS accumulation [40]. Similarly, there are several other bioactive dietary polyphenols including quercetin, curcumin, capsaicin, epigallocatechin-3-gallate, piperine, phenethyl isothiocyanate, benzyl isothiocyanate, and others that exert antitumor effects by inducing ROS-mediated cytotoxicity in cancer cells [41].

Other types of anticancer drugs cause cancer cell death by depleting antioxidant levels. For instance, buthionine sulfoximine synergistically affects the chlorin e6 (Ce6)-based photodynamic therapy (PDT) of colorectal cancer cells [42] and several other cancer types including prostate, breast, lung, colon, cervix, bladder, and kidney cancers by inhibiting glutathione [43]. Similarly, imexon-another small-molecule chemotherapeutic agent-disrupts glutathione activity and induces cancer cell death. This agent is widely used in the treatment of advanced cancers of the breast, lung, and prostate [44,45]. Although such anticancer drugs disrupt the redox homeostasis in cancer cells, the inhibition of antioxidant enzymes may also introduce the liability of causing deleterious side effects in normal tissues and organs.

\section{Cancer Preventive Role of Curcumin through Suppression of Free Radicals}

As described above, ROS plays a key role in carcinogenesis. Therefore, reducing ROS levels can reserve the initiation of tumorigenesis. Curcumin has shown to be a well-established antioxidant compound by innumerable researchers. Various studies have also shown that curcumin blocks the tumorigenesis process in many rodent carcinogenesis models including skin, duodenal, forestomach, and colon carcinogenesis and therefore works as a chemopreventive agent [46-48]. It regulates multiple cell signaling pathways including oxidative stress and inhibits the initiation of carcinogenesis (Figure 1). The chemopreventive effect of curcumin was found to be enhanced when combined with other chemopreventive agents. 


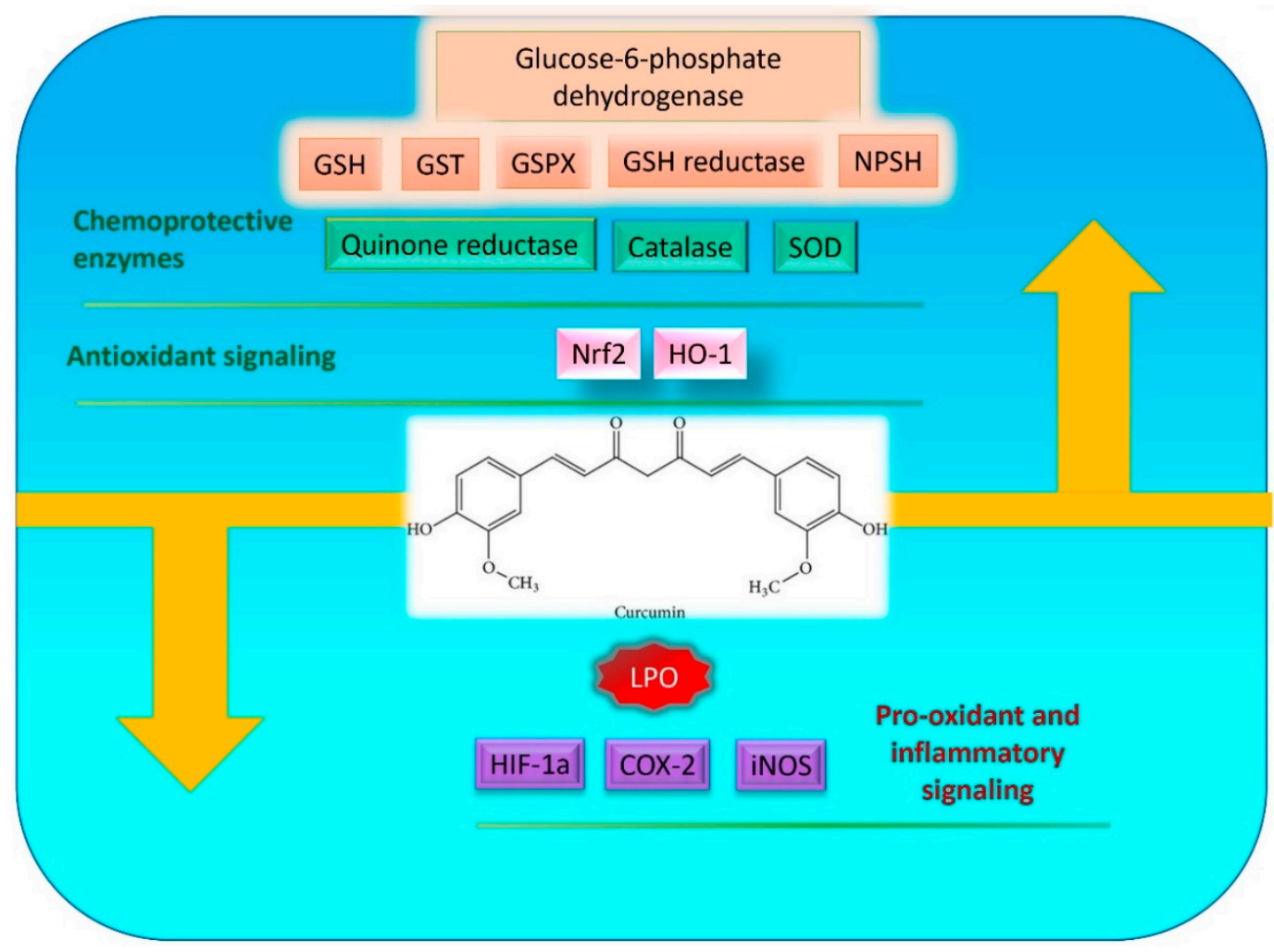

Figure 1. Chemopreventive role of curcumin by suppressing reactive oxygen species (ROS).

\subsection{Curcumin Mediates Chemopreventive Effect through Its Antioxidant Property}

As curcumin has antioxidant activity, it exhibits a chemopreventive effect by reducing ROS levels and by inducing antioxidant enzymes (Table 1). In a study, curcumin has shown chemopreventive property by suppressing colon carcinogenesis in azoxymethane-dextran sulfate sodium (AOM-DSS) treated mice. The chemopreventive effect of curcumin was found to be associated with the downregulation of multiple regulatory pathways including oxidative stress, as analyzed by RNA sequencing of tumors [49]. In another study, curcumin was found to prevent amino-1-methyl-6-phenylimidazo [4,5-b]pyridine (PhIP)-induced cytotoxicity in normal breast epithelial cells. It has been shown that curcumin prevents PhIP-induced DNA adduct formation and DNA double stand breaks through induction of various antioxidant enzyme systems [50]. Curcumin has also been shown to have protective effect against lung carcinogenesis through its antioxidant property. Curcumin at a dose of $60 \mathrm{mg} / \mathrm{kg}$ in drinking water suppressed benzopyrene induced ROS and lipid peroxidation in mice. Moreover, curcumin restored benzopyrene-induced reduced level of glutathione in mice, indicating the protective role of curcumin as an antioxidant [51]. Curcumin also inhibited methylglyoxal (MG)-induced apoptotic events in human hepatoma G2 cells. It has been found that curcumin abolishes MG-stimulated intracellular ROS formation, and subsequent apoptotic biochemical changes in hepatoma G2 cells [52].

Curcumin also exhibits potential benefit against arsenic-induced oxidative stress in humans. A field trial was conducted in volunteers consuming arsenic contaminated ground water. Among 286 volunteers, half were treated with curcumin (500 $\mathrm{mg}$ twice daily) and remaining half were assigned with placebo. After three months, DNA damage and oxidative stress were analyzed in blood. The blood samples from endemic regions showed severe DNA damage with increased levels of ROS and lipid peroxidation. The antioxidant enzymes showed depleted activity in the placebo treated group. However, curcumin intervention reduced the DNA damage, retarded ROS generation and lipid peroxidation and raised the level of antioxidant activity [53]. Thus, curcumin exhibits a protective role in humans. 
Table 1. Cancer preventive properties of curcumin mediated through inhibition of oxidative stress.

\begin{tabular}{|c|c|c|c|}
\hline Properties & Models & Mechanisms & References \\
\hline \multirow{4}{*}{ Anti-carcinogenesis } & \multirow{2}{*}{ BP-induced lung tumor in mice } & $\begin{array}{l}\text { Decreases the levels of LPO, ROS, } \\
\text { as well as increases activities of SOD, GST }\end{array}$ & [51] \\
\hline & & $\begin{array}{l}\text { In combination with resveratrol, decreases the LPO level } \\
\text { and restores activities of SOD, GR, and GST }\end{array}$ & [54] \\
\hline & CoCl2-induced hypoxia in HCC & $\begin{array}{l}\text { decreased hypoxia-induced HIF- } 1 \alpha \text { protein, suppressed cell proliferation, } \\
\text { migration and invasiveness, as well as EMT changes }\end{array}$ & [55] \\
\hline & AOM-DSS-induced colon cancer in mice & Decreases DNA CpG methylation of Tnf & [49] \\
\hline \multirow{5}{*}{ Chemopreventive } & ddY mice & $\begin{array}{l}\text { Increases the activity of antioxidant enzymes GPx, GR, } \\
\text { glucose-6-phosphate dehydrogenase and catalase }\end{array}$ & [57] \\
\hline & Sprague-Dawley rats. & Increases activity of GST enzyme & [58] \\
\hline & Renal epithelial cells & Stimulates the expression of Nrf2, increases in $\mathrm{HO}-1$ & [59] \\
\hline & Bovine aortic endothelial cells & Increases the expression of $\mathrm{HO}-1 \mathrm{mRNA}$, protein and its activity & [60] \\
\hline & Spontaneous ovarian cancer in hen & $\begin{array}{l}\text { Reduces tumor sizes and number, inhibits NF-kB and STAT3 signaling } \\
\text { pathways, decreases KRAS and HRAS mutations, and induces NRF2/HO-1 } \\
\text { antioxidant pathway }\end{array}$ & [61] \\
\hline \multirow[t]{2}{*}{ Chemoprotective } & Hemin-induced cytotoxicity in rat neurons. & $\begin{array}{l}\text { Attenuates ROS production, reduces GSH/GSSG ratio, increases GR, GST } \\
\text { and SOD enzymes, increases HO- } 1 \text { level and Nrf2 translocation into the } \\
\text { nucleus, and reduces cell death }\end{array}$ & [62] \\
\hline & TAA-induced liver inflammation and fibrosis in rats & $\begin{array}{l}\text { Reduces oxidative stress, inhibits apoptosis, induced autophagy, decreases } \\
\text { fetoprotein AST activity, and increased serum albumin concentration. }\end{array}$ & [63] \\
\hline \multirow[t]{3}{*}{ Anti-cytotoxic } & PhIP-induced cytotoxicity in breast epithelial cells & $\begin{array}{l}\text { Decreases ROS production, inhibits DNA adduct formation and DNA } \\
\text { double stand breaks, and induces expression of various antioxidant and } \\
\text { DNA repair genes }\end{array}$ & [50] \\
\hline & Dox-induced cytotoxicity in 3T3 normal cells & $\begin{array}{l}\text { With resveratrol and EEAC increases cell antioxidant ability by improving } \\
\text { the activity of SOD, prevents intracellular damage, and reduces ROS }\end{array}$ & [64] \\
\hline & MG-induced cell death in human hepatoma G2 cells & $\begin{array}{l}\text { Abolishes oxidative stress, prevents apoptotic biochemical changes such as } \\
\text { release of cytochrome c, caspase-3 activation, and cleavage of PARP }\end{array}$ & [52] \\
\hline
\end{tabular}


Curcumin also exerts chemopreventive efficacy by increasing the activity of antioxidant enzymes and phase II-metabolic enzymes in the liver and kidneys. Curcumin ( $2 \%)$ when fed to mice for 30 days showed a significant enhancement in the activities of glutathione peroxidase, glutathione reductase, glucose-6-phosphate dehydrogenase, and catalase. In addition, curcumin enhances the activities of glutathione $S$-transferase and quinone reductase. This suggests that curcumin may prevent liver and kidney carcinogenesis by inducing antioxidant enzymes [57]. Moreover, in an in vivo rat model, curcumin decreased the oxidative stress levels and showed a dose dependent increase in the NPSH levels in rat liver, which corresponds roughly to tissue glutathione content. Glutathione peroxidase activity was also found to be elevated with increasing curcumin dosing [58], while it reduced lipid peroxidation and salvaged hepatic glutathione antioxidant defense in rats [65]. Such observations clearly point towards the chemopreventive actions of curcumin by inhibiting ROS and inducing antioxidant activities.

The transcription factor Nrf2 is believed to be one of the crucial players in regulating the various antioxidant genes including hemeoxygenase (HO-1). Activation of the Nrf2 antioxidant pathway signaling is reported to play an important role in cancer prevention [66]. Interestingly, curcumin has been shown to activate Nrf2 and HO-1 signaling. In one study, curcumin activated Nrf2 by promoting its nuclear translocation in a time-dependent manner in neuronal cells, and also induced HO-1 protein levels in a concentration-dependent manner [62]. Similarly, curcumin treatment also promoted translocation of Nrf2 protein into the nucleus in renal epithelial cells. This translocation was associated with elevated HO-1 activity [59]. In addition, curcumin treatment increased the expression of HO-1 in vascular endothelial cells leading to the alleviation of oxidative damage [60]. It has also been shown that dietary curcumin consumption at a dose of $53 \mathrm{mg} /$ day reduced ovarian cancer incidence in hens. Curcumin was mixed with a basal diet and were mixed homogenously. This curcumin mixed diet was administered to hens. Interestingly, this chemopreventive effect of curcumin was found to be mediated through reduction in oxidative stress and lipid peroxidation in serum and ovarian tissues. The mechanism behind the chemopreventive effect of curcumin in hen ovarian tissue was an upregulation of antioxidant related proteins such as Nrf2 and HO-1 [61]. Another transcription factor, hypoxia-inducible factor 1 (HIF-1) is known to be associated with increased ROS levels in hypoxic conditions $[67,68]$. In vitro studies have indicated that curcumin can inhibit the expression of HIF-1 in hepatic carcinoma cells $[55,69]$, possibly suggesting the inhibition of hypoxia-induced ROS by curcumin.

Curcumin is a known potent anti-inflammatory agent that prevents tumor progression and exerts a chemopreventive effect on carcinogenesis via suppressing inflammation. Increasing evidences suggest the involvement of ROS as a mechanism by which chronic inflammation drives cancer initiation and progression. Chronic inflammation stimulates ROS generation which leads to tissue injury and promotes carcinogenesis [70-72]. TNF $\alpha$ is an inflammatory cytokine that activates NF- $\mathrm{kB}$ and increases expression of other inflammatory enzymes such as COX-2 and inducible nitric oxide synthase (iNOS). Importantly, studies support that a positive feedback loop between TNF $\alpha$ and ROS promote inflammation-induced carcinogenesis [73-76]. Curcumin has shown to prevent colon carcinogenesis in mice and cholangiocarcinogenesis in hamsters by suppressing the expression of pro-inflammatory enzymes iNOS and COX-2 [77,78]. Curcumin also reduced the iNOS mRNA expression in ex vivo cultured macrophages in a concentration-dependent manner [79]. Moreover, it inhibits thioacetamide (TAA)-induced liver inflammation and fibrosis in rats. It further reduced oxidative stress in liver, inhibited apoptosis, and induced autophagy, and thus protects the first dysplastic stage of hepatocellular carcinoma (HCC) in rats [63]. These studies suggest the potential benefit of curcumin as a chemopreventive agent by suppressing inflammation induced ROS.

Considering the poor absorption and bioavailability of curcumin, several analogues of curcumin have been synthesized and optimized for better antioxidant properties [80]. Dimethoxy curcumin, when tested in human peripheral blood mononuclear cells showed a decrease in lipid peroxidation status and an increase in the catalase activity [81]. In another study, efforts have been directed 
towards synthesizing curcumin derivatives as Nrf2 activators. Curcumin nanoparticles as polylactide co-glycolide (PLGA) nanocapsulated curcumin have shown chemopreventive activity against diethylnitrosamine (DEN) induced HCC in rat. Oral administration of curcumin nanoparticles ( $20 \mathrm{mg} / \mathrm{kg}$ body weight for 16 weeks) in DEN induced HCC rats exerted a significant protection against HCC by restoring redox homeostasis in liver cells [56]. In order to enhance solubility of curcumin, it is encapsulated with biodegradable nanoparticulate formulation based on PLGA and a stabilizer polyethylene glycol (PEG)-5000. In line with the previous studies, the synthesized compounds were found to be cytoprotective against oxidative stress [82].

\subsection{Chemopreventive Potential of Curcumin in Combination with Other Compounds}

The chemopreventive efficacy of curcumin has been evaluated in combination with several other natural and synthetic compounds. Interestingly, the chemopreventive potential of curcumin in combination with resveratrol has been shown in multiple studies. Curcumin in combination with resveratrol prevented lung carcinogenesis in rats [83]. In a study, supplementation with curcumin and resveratrol to benzo(a)pyrene-treated mice resulted in the diminution of the molecular events during the promotional phase of lung carcinogenesis. Curcumin $(60 \mathrm{mg} / \mathrm{kg}$ orally in drinking water) and resveratrol $(5.7 \mu \mathrm{g} / \mathrm{mL}$ orally in drinking water) were administered individually or in combination-3 times a week for a total duration of 22 weeks-to benzo(a)pyrene-treated mice. Supplementation of curcumin and resveratrol alone resulted in improvement in cellular integrity, nuclear deformation and premature mitochondrial senescence, however the effects were potentiated with the combined supplementation of phytochemicals [84]. Benzo(a)pyrene treatment also caused significant increase in the levels of lipid peroxidation along with reduction in glutathione levels and the decreased activities of SOD in lungs of mice. Administration of curcumin and resveratrol to benzo(a)pyrene-treated mice decreased the levels of lipid peroxidation and elevated the activities of SOD respectively. Further, the combination also showed an increase in the levels of both reduced glutathione and SOD activity along with decreased level of lipid peroxidation when compared with the monotherapy [85]. Another study showed that treatment of resveratrol and curcumin in combination significantly decreased the benzo(a)pyrene-induced lipid peroxidation, and restored several antioxidant enzymes including SOD, GR, and GST, which eventually may have contributed to lung cancer prevention [54]. Interestingly, curcumin has shown to reduce doxorubicin-induced cardiotoxicity by inhibiting production of ROS. Additionally, curcumin has synergistic effects with doxorubicin against MCF-7 breast cancer cells [64]. Thus, use of curcumin as an adjuvant, alongside other chemopreventive agents could have substantial clinical implications to further develop novel modalities for chemoprevention.

\section{Cancer Therapeutic Role of Curcumin through Induction of ROS}

The cancer therapeutic benefits of curcumin have been demonstrated in multiple types of cancers including, breast, prostate, skin, lung, liver, brain, stomach, cervical, ovary, multiple myeloma, leukemia and several other types of cancer [86]. Prior experimental evidences have shown that curcumin is effective in potentiating and enhancing anticancer effects of other cancer therapeutic drugs. Moreover, it sensitizes the drug resistant cells and increases therapeutic potential of anticancer drugs [87]. At the molecular level, curcumin exerts anticancer and chemosensitizing effects by targeting multiple pathways including ROS mediated cell signaling (Figure 2). 


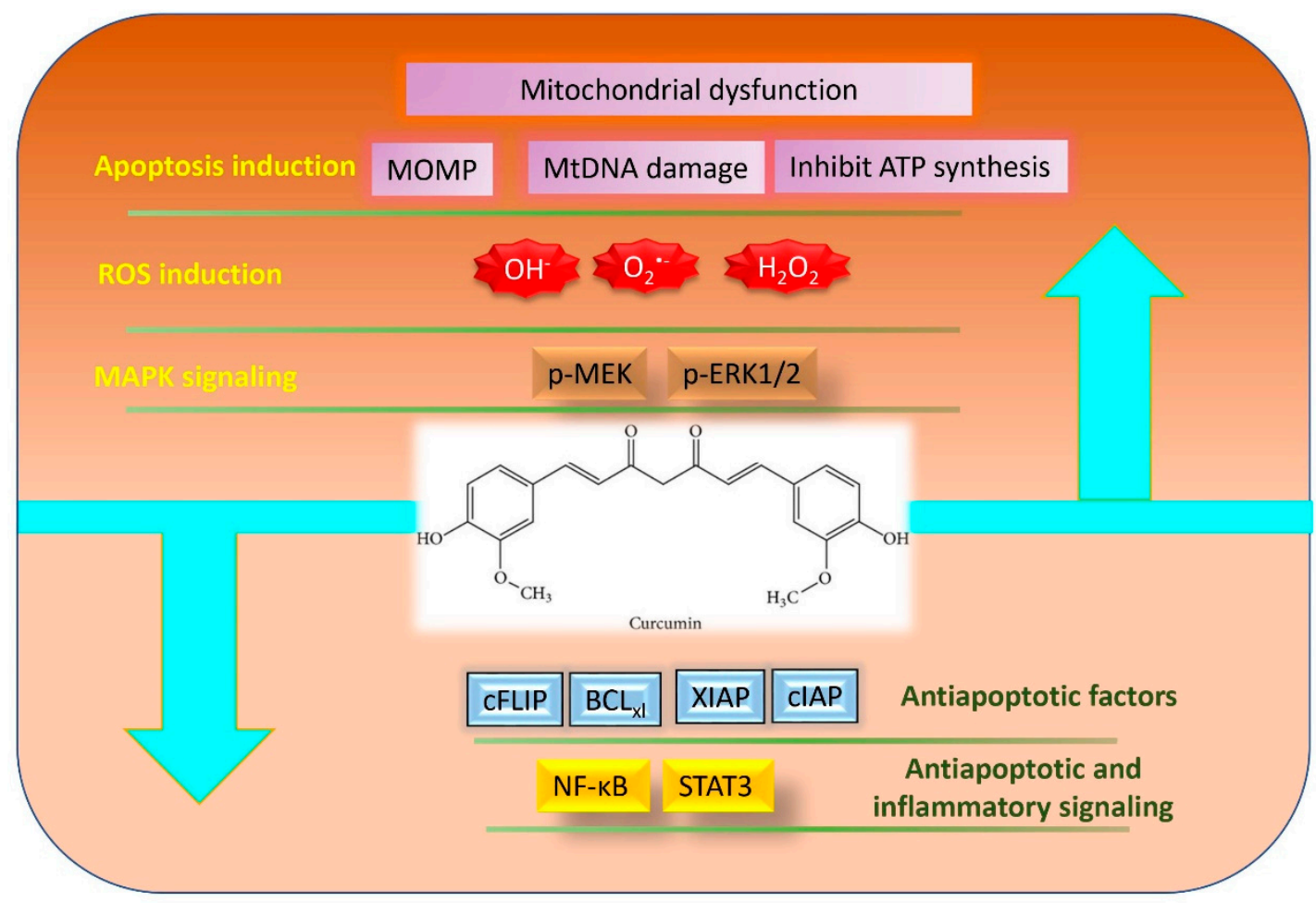

Figure 2. Chemotherapeutic role of curcumin mediated through induction of ROS.

\subsection{ROS Mediated Anticancer Effect of Curcumin}

Along with chemopreventive properties, curcumin has also chemotherapeutic effects against different types of cancers through multiple mechanisms including oxidative stress pathway (Table 2). Curcumin regulates cellular redox balance by disrupting mitochondrial homeostasis and enhancing cellular oxidative stress. It oxidizes thiols in the mitochondrial membrane, triggers opening of mitochondrial permeability transition pore, mitochondrial swelling, loss of mitochondrial membrane potential, and inhibition of ATP synthesis, leading to initiation of cellular apoptosis in cancer cells [88]. Curcumin further increases the generation of variety of ROS, including hydroxy radicals, superoxides, and $\mathrm{H}_{2} \mathrm{O}_{2}$ [89,90]. Indeed, in gastric cancer cells curcumin induced the generation of excessive ROS that resulted in depletion of mtDNA and POLG (polymerase $\gamma$ that reduce mitochondrial oxygen consumption) and subsequent occurrence of cell death [91]. Furthermore, curcumin induces ROS production and decreases mitochondrial transmembrane potential thereby activating DNA damage/repair pathway and mitochondrial apoptosis. Similarly, curcumin exhibited cytotoxicity in NSCLC through the accumulation of cellular ROS. The involvement of ROS was confirmed by using ROS scavengers like catalase and N-acetyl-l-cysteine (NAC) that reversed curcumin-induced cell death in NSCLC [92]. 
Table 2. Cancer therapeutic properties of curcumin and its analogues mediated through generation.

\begin{tabular}{|c|c|c|c|}
\hline Properties & Models & Mechanism & Reference \\
\hline \multirow{5}{*}{ Apoptosis } & Myeloid leukemia K562 cells & Releases cytochrome c from mitochondria, PARP and caspase-9 cleavages & [93] \\
\hline & Melanoma A375 cells & Induces ROS burst, decreases GSH, and wrecks MMP & [94] \\
\hline & Gastric cancer BGC-823 cells & Induces ROS, activates ASK1, and phosphorylates JNK protein & [95] \\
\hline & Leukemic Jurkat and K562 cells & Downregulates IAPs, pAkt, c-Myc, and cyclin D1 & [96] \\
\hline & Breast cancer MCF-7, MDAMB, HepG2 cells & Generates ROS & [97] \\
\hline Cell cycle arrest & Breast cancer MCF-7 cells & Downregulates cyclin B1, Cdc2 and NF- $\mathrm{kB}$ by decreasing the interaction of pI $\mathrm{kB}-\mathrm{NF}-\mathrm{kB}$ & [98] \\
\hline \multirow{6}{*}{ Cell cycle arrest and apoptosis } & HT-29 colon cancer cells & Induced ROS generation, DNA fragmentation, chromatin condensation, and nuclear shrinkage & [99] \\
\hline & K562 cells and xenograft mouse & $\begin{array}{l}\text { Derivative PGV-1 induces prometaphase arrest in the M phase } \\
\text { and induces cell senescence and death by increasing ROS. }\end{array}$ & [100] \\
\hline & $\begin{array}{l}\text { Prostate carcinoma } \\
\text { PC-3 and DU145 and xenograft mice }\end{array}$ & Analogue Ca 37 induces ROS production & [101] \\
\hline & $\begin{array}{l}\text { Prostate cancer RM-1 and DU145 } \\
\text { cell lines and xenograft mice }\end{array}$ & Analog WZ35 induces ROS overproduction, intracellular calcium surge, and mitochondrial disruption & [102] \\
\hline & NCI-H460 cells & $\begin{array}{l}\text { Analogues hexamethoxy-diarylpentadienones (1 and 2) upregulate p53 and p21 and downregulate } \\
\text { Cdc25C, cyclin B1/Cdk1 in a Michael acceptor- and ROS-dependent fashion }\end{array}$ & [103] \\
\hline & NSCLC A549 and SPC-A1 cell lines & Causes ROS production, DNA damage, endoplasmic reticulum stress and mitochondrial instability. & [92] \\
\hline Chemosensitization & Glioblastoma & $\begin{array}{l}\text { DMC synergistically increases TMZ-induced apoptosis by increasing ROS production, } \\
\text { inactivating JAK/STAT3 signaling pathway and caspase-3 cleavage }\end{array}$ & [104] \\
\hline Anti-tumorigenesis & CML-derived K562 cells, xenograft mouse & $\begin{array}{l}\text { Derivatives upregulate ROS levels, compete with co-enzymes to bind to } \\
\text { the respective ROS metabolic enzymes and inhibit their activities }\end{array}$ & [105] \\
\hline Anti-angiogenesis & HUVECs, CAMs & Analog A2 induces NADH/NADPH oxidase-derived ROS & [106] \\
\hline $\begin{array}{l}\text { Tumor re-incidence and } \\
\text { metastasis inhibition }\end{array}$ & B16F10 cells, syngeneic mice & Nanoformulation increases intracellular curcumin accumulation and ROS formation & [107] \\
\hline \multirow{2}{*}{ Anti-tumorigenesis } & Gastric cancer BGC-823 cells, xenograft mice & Enhances oxidative stress, decreases mtDNA content and DNA polymerase $\gamma$ & [91] \\
\hline & Leukemic K562 cells, xenograft mice & Induces ROS level & [108] \\
\hline Autophagy and apoptosis & lymphoma HuT-78 cells & $\begin{array}{l}\text { Produces ROS, inhibits c-FLIP, Bcl-xL, cIAP, XIAP, disrupts the integrity of IKK and beclin-1 by } \\
\text { degrading Hsp90, inhibits NF-KB, accumulates autophagy marker LC3-I }\end{array}$ & [109] \\
\hline Autophagy & Colon cancer HCT116 cells & Generates ROS, converts autophagic marker LC3-I to LC3-II and degrades sequestome-1 & [110] \\
\hline
\end{tabular}

MMP—matrix metallopeptidase, ASK1—apoptosis signal-regulating kinase 1, IAPs—inhibitors of apoptosis proteins, JAK—Janus kinase, STAT3—signal transducer and activator of transcription 3, mtDNA-mitochondrial DNA, GSH—glutathione, ROS-reactive oxygen species. 
It has also been observed that the treatment of leukemic cells with curcumin increases intracellular ROS levels over a threshold which was found to be linked with the induction of anti-tumorigenic activity [108]. In melanoma A375 cells, curcumin-induced cell death was also found to be associated with increased oxidative stress. It has been shown that curcumin causes oxidative stress through inducing ROS burst, decreasing glutathione, and wrecking mitochondria membrane potential (MMP), which were reversed by ROS inhibitor NAC [94]. Curcumin also affects the signaling pathways regulated by ROS. In human gastric cancer BGC-823 cells, curcumin induced apoptosis through the generation of ROS as evidenced by the inhibition of curcumin-mediated apoptosis upon antioxidant (NAC or trion) application. Notably, it has been observed that curcumin activated oxidative stress-related kinase ASK1, up-regulated an upstream effector of JNK, MKK4, and phosphorylated JNK protein expression in BGC-823 cells [95]. The modulation of these proteins by curcumin resulted in apoptosis in BGC-823 cells. Similarly, in colon cancer cells, curcumin treatment markedly decreased its cell viability and proliferation potential through generation of ROS. However, the pretreatment with NAC suppressed the growth inhibitory effect of curcumin on HT-29 cells [99].

Along with ROS production, depletion of antioxidant enzymes enhances the anticancer property of curcumin. In a study, curcumin suppressed the growth of human leukemic cells via ROS-independent glutathione depletion, which leads to caspase activation and further apoptosis in leukemic cells. Curcumin treatment to leukemic cells also downregulates the expression of the inhibitor of apoptosis proteins (IAPs), phospho-Akt, c-Myc, and cyclin D1, probably through the suppression of glutathione [96]. In another study, curcumin induced apoptosis in MCF-7, MDAMB-231, and HepG2 cells through generation of ROS. However, depletion of glutathione by buthionine sulfoximine resulted in increased generation of ROS and that enhanced curcumin-mediated apoptosis [97]. It has been reported that curcumin causes rapid generation of ROS in human cutaneous T-cell lymphoma (HuT-78) cells. This increased ROS further modulated different cell survival and cell death pathways and subsequently induced apoptosis. Curcumin also downregulates the expression of antiapoptotic proteins c-FLIP, Bcl-xL, cellular inhibitor of apoptosis protein (cIAP), and X-linked IAP (XIAP) in a ROS-dependent manner, which further induces cancer cell death [109]. Besides apoptosis, curcumin also induces autophagic cell death in HCT116 human colon cancer cell by inducing ROS production [110]. Curcumin also hinders cancer stemness through production of ROS. It inhibits proliferation, sphere forming and colony forming abilities of glioblastoma [111] and liver cancer [112] stem cells by ROS mediated activation of MAPK pathway, suppression of NF- $\mathrm{kB}$ signaling, downregulation of STAT3 activity and IAP family members.

Besides curcumin, its analogues (Figure 3) also exhibit ROS mediated chemotherapeutic activity against various cancers. In a study, curcumin analogue 1,5-bis(3-hydroxyphenyl)-1,4-pentadiene-3-one (Ca 37), which is a monocarbonyl analogue of curcumin, exhibited antitumor activity in both in vitro and in prostate xenografted tumor models. Furthermore, a combination of Ca 37 and curcumin resulted in enhanced antitumor activity in prostate cancer cells. However, administration of ROS quencher NAC abrogated Ca 37 mediated tumor growth inhibition; indicating that induction of ROS plays a vital role in the growth inhibitory activity of Ca 37 in prostate cancer cells [101]. In another study, two symmetrical hexamethoxy-diarylpentadienones (1 and 2) monocarbonyl analogues of curcumin have been reported to possess significantly enhanced cytotoxicity as compared to the parent molecule. In comparison to curcumin, these analogues induce a more potent burst of ROS [103]. WZ35, another structural monocarbonyl analogue of curcumin, was examined for anti-prostate cancer effects in both in vitro and in vivo models and showed a reduction in cancer cell viability, an increase in apoptosis, and G2/M cell cycle arrest through overproduction of ROS. Interestingly, WZ35-induced apoptosis in prostate cancer cells was found to be completely reversed by ROS inhibition. Additionally, in an animal study, WZ35 inhibited prostate homograft tumor growth with increased ROS accumulation, mitochondrial disruption, and cell apoptosis in tumor tissues [102], indicating ROS plays a key role in mediating WZ35 tumor growth inhibition. 
<smiles>COc1cc(/C=C/C(=O)/C=C/c2cccc([N+](=O)[O-])c2)ccc1O</smiles><smiles>COc1cc(OC)c(/C=C/C(=O)/C=C/c2cc(OC)cc(OC)c2OC)c(OC)c1</smiles><smiles>COc1ccc(/C=C/C(=O)/C=C(O)/C=C/c2ccc(OC)c(OC)c2)cc1OC</smiles>

DMC<smiles>COc1cc(/C=C/C(=O)CC(=O)/C=C/c2ccc(OC(=O)COC(=O)C(C)O)c(OC)c2)ccc1O</smiles>

PLGA-Curcumin Conjugate

Figure 3. Chemical structure of curcumin analogues, which exhibits anticancer effects mediated through ROS.

Another monocarbonyl analogue of curcumin, A2 without the $\beta$-diketone moiety, displayed antiangiogenic activity. It has been demonstrated that $\mathbf{A} 2$ exerts its antiangiogenic activity mainly through inducing endothelial cell death via elevating NADH/NADPH oxidase-derived ROS [106]. Furthermore, curcumin analogue pentagamavunon-1 (PGV-1) has been studied for its inhibitory activity on tumor cells in vitro and in vivo. PGV-1 (2,5-bis-(4-hydroxy, 3',5'-dimethyl)-benzylidine-cyclopentanone) is a monocarbonyl analogue of curcumin and has stronger potency than the lead compound, curcumin. It has been found that PGV-1 exhibits 60-fold higher efficacy compared to that of curcumin in inhibiting K562 cell growth. PGV-1 also inhibited the proliferation of leukemia, breast adenocarcinoma, cervical cancer, uterine cancer, and pancreatic cancer cells. Interestingly, PGV-1-induced cell death is mediated by an increase in intracellular ROS levels through inhibition of ROS-metabolic enzymes [100]. Nakamae et al. (2019) synthesized 39 novel curcumin derivatives and examined their anti-proliferative and anti-tumorigenic properties. They found that these analogues exhibit anti-proliferative activity toward human cancer cell lines in a manner sensitive to antioxidant NAC. Some analogues markedly increased ROS levels and efficiently induced cell death as well as suppressed tumor formation in a xenograft mouse model. Finally, it was found that the anti-tumorigenic activity of these analogues was well-correlated with an increase in ROS levels [105]. Furthermore, nanoformulation of curcumin (curcumin-loaded nanoemulsion) increased intracellular curcumin accumulation and ROS formation, while preventing migration and invasion of melanoma cells [107].

\subsection{Chemosensitizing Effect of Curcumin Mediated through ROS}

Accumulated preclinical evidences suggest that the effectiveness of chemotherapy is being limited due to drug resistance, therapeutic selectivity, and undesirable side effects. In this regard, curcumin has proved its ability to sensitize drug-resistant cancer cells and enhance therapeutic efficacy of drugs. As ROS production by curcumin plays a pivotal role in cancer cell death, it can also mediate chemosensitization. Studies showed that curcumin improves the sensitivity of cancer cells to chemotherapy drugs by regulating a variety of signaling pathways [113]. An in vitro study demonstrated that cisplatin in combination with curcumin exhibit higher anti-tumor activity in HepG2 cells compared with mono-drug therapy. This synergistic effect was found to be the result of increased intracellular ROS levels in HCC cells [114]. Another study showed that curcumin also exhibits a pro-oxidant effect and exerts a chemosensitive property. It sensitizes cisplatin-resistant cells by 
targeting Nrf-2, NF-kB and STAT3 phosphorylation [115]. The apoptosis in bladder cancer (253J-Bv and T24) cells was found to be increased when curcumin was treated in combination with cisplatin as compared to single agent treatment. The synergistic induction of apoptosis by curcumin and cisplatin was associated with increased ROS production together with upregulation of p-MEK and p-ERK1/2 signaling [116].

The cancer therapeutic response of curcumin has been shown to be improved by tolfenamic acid (a non-steroidal anti-inflammatory drug). Tolfenamic acid has been reported to inhibit the growth of human cancer cells in vitro and in vivo. However, the combination of tolfenamic acid and curcumin showed higher growth inhibition when compared to either single agent. Further, another study showed that the combination treatment upregulated the ROS level that led to an increase in apoptosis in colorectal cancer cells [117]. Subtoxic concentrations of curcumin has also demonstrated to sensitize human renal cancer cells to the tumor necrosis factor-related apoptosis inducing ligand (TRAIL)-mediated apoptosis. Curcumin induces generation of ROS that led to the expression of death receptor 5 (DR5) and further enhancement in TRAIL mediated apoptosis [118]. An increase in ROS production and mitochondria depolarization by the combined treatment of curcumin and tamoxifen was also observed. This combination of drugs resulted in synergistic induction of autophagy along with apoptosis in chemoresistant melanoma cells, indicating the role of curcumin-induced ROS in combination chemotherapy [119]. ROS generation by curcumin has also been shown to enhance irinotecan's therapeutic effects on colorectal cancer cells by inhibiting cell viability and inducing cell cycle arrest and apoptosis [120]. Curcumin analogue also sensitizes drug-resistant cancer cells. In a study, curcumin analog ALZ003 inhibited the survival of TMZ-sensitive and -resistant glioblastoma in both in vitro and in vivo models through the accumulation of ROS, lipid peroxidation and suppression of GPX4 [121]. Demethoxycurcumin (DMC), a naturally occurring curcumin analogue has been shown to enhance antitumor effect of temozolomide (TMZ). In a study, treatment of DMC prior to TMZ in glioblastoma cells resulted in a significant increase in caspase- 3 signaling, mitochondria-related apoptosis and a marked inhibition of cell growth in vitro through production of ROS as well as inactivation of JAK/STAT3 signaling pathway [104].

Combinations of drugs may enhance the therapeutic effect of individual drug treatment. Combinations of natural products are broadly explored in cancer therapy. In a study, curcumin was combined with arabinogalactan (found in Larch trees) and treated to the human breast cancer cells. This combination promoted cell growth inhibition and apoptosis induction in human breast cancer cells by increasing ROS level as well as loss of mitochondrial membrane potential and reduction of glutathione. In addition, this combination inhibited the progression of breast tumors in mouse model [122]. It has been observed that curcumin in combination with quercetin induced apoptosis by increasing ROS and decreasing glutathione levels, as well as by inducing loss of mitochondrial membrane potential. The combination of quercetin and curcumin potentiates individual's apoptotic effect and reduces effective dose of individual agent [93]. Nanoparticles loaded with curcumin and quercetin have also shown synergistic antitumor properties on a breast cancer cell line. Cell viability study showed a pronounced antitumor effect in combination compared to the individual drug on the MCF7 cell line, which was associated with an increase in intracellular ROS level [123]. Curcumin and resveratrol have also been found to exhibit a synergistic anticancer effect in colon cancer. The combination of curcumin and resveratrol has shown to upregulate intracellular ROS levels and further elicit a synergistic antiproliferative effect in Hepa1-6 cells [124]. Besides these, there are several natural compounds as well as therapeutic drugs that have shown to exhibit synergistic anticancer effect with curcumin mediated by ROS induction.

\section{Conclusions}

Oxidative stress-caused by an imbalance between free radical generation and the antioxidant defense system of the body-potentially results in the initiation and progression of cancer. However, free radicals, specially ROS, play an important role in therapeutic drug action. Thus, ROS has both 
pathological and pharmacological importance in the body. These findings suggest the use of strategies to either suppress or induce ROS. One of the strategies is to decrease oxidative stress by quenching ROS and/or increasing antioxidant enzymes that can subsequently inhibit carcinogenesis. Another strategy is to use ROS inducing agents in cancer patients that can induce apoptosis in cancer cells. Use of antioxidants in cancer patients have shown unfavorable results for the treatment efficacy of therapeutic drugs. Studies have shown that antioxidants cause increased cancer incidences, probably due to the inhibition of ROS mediated apoptosis of cancer cells. However, high consumption of fruits and vegetables rich in antioxidants are associated with decreased risk of cancer incidence. In view of this, curcumin is considered as an antioxidant as well as a prooxidant, since it reduces oxidative stress in normal cells and induces ROS production in cancer cells. Although several studies have investigated the beneficial role of curcumin, this review will help to better understand the ROS associated chemopreventive and anticancer mechanism of curcumin.

Author Contributions: S.P. contributed to the concept, design and to the writing of the manuscript; N.G., K.V. and S.N. contributed to the literature search and writing of manuscript; A.K. and R.L. reviewed and provided feedback in the manuscript designing and writing. All authors have read and agreed to the published version of the manuscript.

Funding: This research received no external funding. APC was sponsored by MDPI.

Acknowledgments: We thank Shyanne Page-Hefley from the Department of Pediatrics for carefully proofreading the manuscript.

Conflicts of Interest: The authors declare no conflict of interest.

\section{References}

1. Kurutas, E.B. The importance of antioxidants which play the role in cellular response against oxidative/nitrosative stress: Current state. Nutr. J. 2015, 15, 1-22. [CrossRef] [PubMed]

2. Cheeseman, K.; Slater, T. An introduction to free radical biochemistry. Br. Med. Bull. 1993, 49, 481-493. [CrossRef] [PubMed]

3. Liu, T.; Stern, A.; Roberts, L.J.; Morrow, J.D. The isoprostanes: Novel prostaglandin-like products of the free radical-catalyzed peroxidation of arachidonic acid. J. Biomed. Sci. 1999, 6, 226-235. [CrossRef] [PubMed]

4. Lea, A. Dietary factors associated with death-rates from certain neoplasms in man. Lancet 1966, 2, $332-333$. [CrossRef]

5. Key, T.J.; Bradbury, K.E.; Perez-Cornago, A.; Sinha, R.; Tsilidis, K.K.; Tsugane, S. Diet, nutrition, and cancer risk: What do we know and what is the way forward? BMJ 2020, 368. [CrossRef]

6. Neuhouser, M.L.; Barnett, M.J.; Kristal, A.R.; Ambrosone, C.B.; King, I.B.; Thornquist, M.; Goodman, G.G. Dietary supplement use and prostate cancer risk in the Carotene and Retinol Efficacy Trial. Cancer Epidemiol. Prev. Biomark. 2009, 18, 2202-2206. [CrossRef]

7. Goodman, G.E.; Thornquist, M.D.; Balmes, J.; Cullen, M.R.; Meyskens, F.L., Jr.; Omenn, G.S.; Valanis, B.; Williams, J.H., Jr. The Beta-Carotene and Retinol Efficacy Trial: Incidence of lung cancer and cardiovascular disease mortality during 6-year follow-up after stopping $\beta$-carotene and retinol supplements. J. Natl. Cancer Inst. 2004, 96, 1743-1750. [CrossRef]

8. Wiel, C.; Le Gal, K.; Ibrahim, M.X.; Jahangir, C.A.; Kashif, M.; Yao, H.; Ziegler, D.V.; Xu, X.; Ghosh, T.; Mondal, T. BACH1 stabilization by antioxidants stimulates lung cancer metastasis. Cell 2019, 178, 330-345.e22. [CrossRef]

9. Sinha, B.K. Free radicals in anticancer drug pharmacology. Chem. Biol. Interact. 1989, 69, 293-317. [CrossRef]

10. Martin, K.; Barrett, J. Reactive oxygen species as double-edged swords in cellular processes: Low-dose cell signaling versus high-dose toxicity. Hum. Exp. Toxicol. 2002, 21, 71-75. [CrossRef]

11. Pan, J.-S.; Hong, M.-Z.; Ren, J.-L. Reactive oxygen species: A double-edged sword in oncogenesis. World J. Gastroenterol. WJG 2009, 15, 1702. [CrossRef] [PubMed]

12. Phaniendra, A.; Jestadi, D.B.; Periyasamy, L. Free radicals: Properties, sources, targets, and their implication in various diseases. Indian J. Clin. Biochem. 2015, 30, 11-26. [CrossRef] [PubMed]

13. Du, M.Q.; Carmichael, P.L.; Phillips, D.H. Induction of activating mutations in the human c-Ha-ras-1 proto-oncogene by oxygen free radicals. Mol. Carcinog. 1994, 11, 170-175. [CrossRef] [PubMed] 
14. Wang, D.; Kreutzer, D.A.; Essigmann, J.M. Mutagenicity and repair of oxidative DNA damage: Insights from studies using defined lesions. Mutat. Res. Fundam. Mol. Mech. Mutagenes. 1998, 400, 99-115. [CrossRef]

15. Domínguez, A.G.; Ramírez, L.P.; Monroy, R.H.; Angeles-Angeles, A. Non-Hodgkin's Lymphoma Secondary to Hodgkin's Disease Treated With Chemo-And Radiotherapy. Report of a Case. Rev. Investig. Clin. Organo Hosp. Enferm. Nutr. 1992, 44, 393-398.

16. Olinski, R.; Jaruga, P.; Zastawny, T.H. Oxidative DNA base modifications as factors in carcinogenesis. Acta Biochim. Pol. 1998, 45, 561-572. [CrossRef]

17. Poulsen, H.E.; Prieme, H.; Loft, S. Role of oxidative DNA damage in cancer initiation and promotion. Eur. J. Cancer Prev. 1998, 7, 9-16.

18. Malins, D.C.; Haimanot, R. Major alterations in the nucleotide structure of DNA in cancer of the female breast. Cancer Res. 1991, 51, 5430-5432.

19. Ichiba, M.; Maeta, Y.; Mukoyama, T.; Saeki, T.; Yasui, S.; Kanbe, T.; Okano, J.I.; Tanabe, Y.; Hirooka, Y.; Yamada, S. Expression of 8-hydroxy-2'-deoxyguanosine in chronic liver disease and hepatocellular carcinoma. Liver Int. 2003, 23, 338-345. [CrossRef]

20. Moldogazieva, N.T.; Lutsenko, S.V.; Terentiev, A.A. Reactive Oxygen and Nitrogen Species-Induced Protein Modifications: Implication in Carcinogenesis and Anticancer Therapy. Cancer Res. 2018, 78, 6040-6047. [CrossRef]

21. Barrera, G. Oxidative stress and lipid peroxidation products in cancer progression and therapy. ISRN Oncol. 2012, 2012. [CrossRef]

22. Csala, M.; Kardon, T.; Legeza, B.; Lizák, B.; Mandl, J.; Margittai, É.; Puskás, F.; Száraz, P.; Szelényi, P.; Bánhegyi, G. On the role of 4-hydroxynonenal in health and disease. Biochim. Biophys. Acta (BBA) Mol. Basis Dis. 2015, 1852, 826-838. [CrossRef]

23. Lauschke, H.; Tolba, R.; Burger, B.; Minor, T.; Hirner, A. Lipid peroxidation as additional marker in patients with colorectal cancer. Eur. Surg. Res. 2002, 34, 346-350. [CrossRef]

24. Prasad, S.; Gupta, S.C.; Tyagi, A.K. Reactive oxygen species (ROS) and cancer: Role of antioxidative nutraceuticals. Cancer Lett. 2017, 387, 95-105. [CrossRef]

25. Aykin-Burns, N.; Ahmad, I.M.; Zhu, Y.; Oberley, L.W.; Spitz, D.R. Increased levels of superoxide and H2O2 mediate the differential susceptibility of cancer cells versus normal cells to glucose deprivation. Biochem. J. 2009, 418, 29-37. [CrossRef]

26. Singh, A.; Misra, V.; Thimmulappa, R.K.; Lee, H.; Ames, S.; Hoque, M.O.; Herman, J.G.; Baylin, S.B.; Sidransky, D.; Gabrielson, E. Dysfunctional KEAP1-NRF2 interaction in non-small-cell lung cancer. PLoS Med. 2006, 3, e420. [CrossRef]

27. Neumann, C.A.; Fang, Q. Are peroxiredoxins tumor suppressors? Curr. Opin. Pharmacol. 2007, 7, 375-380. [CrossRef]

28. Wang, J.; Yi, J. Cancer cell killing via ROS: To increase or decrease, that is the question. Cancer Biol. Ther. 2008, 7, 1875-1884. [CrossRef]

29. Khuntia, D.; Mehta, M. Motexafin gadolinium: A clinical review of a novel radioenhancer for brain tumors. Expert Rev. Anticancer. Ther. 2004, 4, 981-989. [CrossRef]

30. Mehta, M.P.; Rodrigus, P.; Terhaard, C.; Rao, A.; Suh, J.; Roa, W.; Souhami, L.; Bezjak, A.; Leibenhaut, M.; Komaki, R. Survival and neurologic outcomes in a randomized trial of motexafin gadolinium and whole-brain radiation therapy in brain metastases. J. Clin. Oncol. 2003, 21, 2529-2536. [CrossRef]

31. Rodrigus, P. Motexafin gadolinium: A possible new radiosensitiser. Expert Opin. Investig. Drugs 2003, 12, 1205-1210. [CrossRef] [PubMed]

32. Kotamraju, S.; Chitambar, C.R.; Kalivendi, S.V.; Joseph, J.; Kalyanaraman, B. Transferrin receptor-dependent iron uptake is responsible for doxorubicin-mediated apoptosis in endothelial cells role of oxidant-induced iron signaling in apoptosis. J. Biol. Chem. 2002, 277, 17179-17187. [CrossRef] [PubMed]

33. Mooberry, S.L. Mechanism of action of 2-methoxyestradiol: New developments. Drug Resist. Updates 2003, 6, 355-361. [CrossRef] [PubMed]

34. Djavaheri-Mergny, M.; Wietzerbin, J.; Besancon, F. 2-Methoxyestradiol induces apoptosis in Ewing sarcoma cells through mitochondrial hydrogen peroxide production. Oncogene 2003, 22, 2558-2567. [CrossRef]

35. Kachadourian, R.; Liochev, S.I.; Cabelli, D.E.; Patel, M.N.; Fridovich, I.; Day, B.J. 2-Methoxyestradiol does not inhibit superoxide dismutase. Arch. Biochem. Biophys. 2001, 392, 349-353. [CrossRef] 
36. Lakhani, N.J.; Sarkar, M.A.; Venitz, J.; Figg, W.D. 2-Methoxyestradiol, a promising anticancer agent. Pharmacother. J. Hum. Pharmacol. Drug Ther. 2003, 23, 165-172. [CrossRef]

37. Mukhopadhyay, T.; Roth, J.A. Superinduction of wild-type p53 protein after 2-methoxyestradiol treatment of Ad5p53-transduced cells induces tumor cell apoptosis. Oncogene 1998, 17, 241-246. [CrossRef]

38. Heo, J.R.; Kim, S.M.; Hwang, K.A.; Kang, J.H.; Choi, K.C. Resveratrol induced reactive oxygen species and endoplasmic reticulum stress-mediated apoptosis, and cell cycle arrest in the A375SM malignant melanoma cell line. Int. J. Mol. Med. 2018, 42, 1427-1435. [CrossRef]

39. Zhang, Y.; Huang, L.; Shi, H.; Chen, H.; Tao, J.; Shen, R.; Wang, T. Ursolic acid enhances the therapeutic effects of oxaliplatin in colorectal cancer by inhibition of drug resistance. Cancer Sci. 2018, 109, 94-102. [CrossRef]

40. Wang, J.; Yuan, Z. Gambogic acid sensitizes ovarian cancer cells to doxorubicin through ROS-mediated apoptosis. Cell Biochem. Biophys. 2013, 67, 199-206. [CrossRef]

41. NavaneethaKrishnan, S.; Rosales, J.L.; Lee, K.-Y. ROS-mediated cancer cell killing through dietary phytochemicals. Oxid. Med. Cell. Longev. 2019, 2019. [CrossRef] [PubMed]

42. Lee, H.M.; Kim, D.H.; Lee, H.L.; Cha, B.; Kang, D.H.; Jeong, Y.-I. Synergistic effect of buthionine sulfoximine on the chlorin e6-based photodynamic treatment of cancer cells. Arch. Pharmacal Res. 2019, 42, 990-999. [CrossRef] [PubMed]

43. Maeda, H.; Hori, S.; Ohizumi, H.; Segawa, T.; Kakehi, Y.; Ogawa, O.; Kakizuka, A. Effective treatment of advanced solid tumors by the combination of arsenic trioxide and L-buthionine-sulfoximine. Cell Death Differ. 2004, 11, 737-746. [CrossRef] [PubMed]

44. Moulder, S.; Dhillon, N.; Ng, C.; Hong, D.; Wheler, J.; Naing, A.; Tse, S.; La Paglia, A.; Dorr, R.; Hersh, E. A phase I trial of imexon, a pro-oxidant, in combination with docetaxel for the treatment of patients with advanced breast, non-small cell lung and prostate cancer. Investig. New Drugs 2010, 28, 634-640. [CrossRef] [PubMed]

45. Sheveleva, E.V.; Landowski, T.H.; Samulitis, B.K.; Bartholomeusz, G.; Powis, G.; Dorr, R.T. Imexon induces an oxidative endoplasmic reticulum stress response in pancreatic cancer cells. Mol. Cancer Res. 2012, 10, 392-400. [CrossRef] [PubMed]

46. Huang, M.-T.; Ma, W.; Lu, Y.-P.; Chang, R.L.; Fisher, C.; Manchand, P.S.; Newmark, H.L.; Conney, A.H.; You, M. Effects of curcumin, demethoxycurcumin, bisdemethoxycurcumin and tetrahydrocurcumin on 12-O-tetradecanoylphorbol-13-acetateinduced tumor promotion. Carcinogenesis 1995, 16, 2493-2497. [CrossRef] [PubMed]

47. Huang, M.-T.; Wang, Z.; Georgiadis, C.; Laskin, J.; Conney, A. Inhibitory effects of curcumin on tumor initiation by benzo [a] pyrene and 7, 12-dimethylbenz [a] anthracene. Carcinogenesis 1992, 13, 2183-2186. [CrossRef]

48. Huang, M.-T.; Lou, Y.-R.; Ma, W.; Newmark, H.L.; Reuhl, K.R.; Conney, A.H. Inhibitory effects of dietary curcumin on forestomach, duodenal, and colon carcinogenesis in mice. Cancer Res. 1994, 54, 5841-5847.

49. Guo, Y.; Wu, R.; Gaspar, J.M.; Sargsyan, D.; Su, Z.-Y.; Zhang, C.; Gao, L.; Cheng, D.; Li, W.; Wang, C. DNA methylome and transcriptome alterations and cancer prevention by curcumin in colitis-accelerated colon cancer in mice. Carcinogenesis 2018, 39, 669-680. [CrossRef]

50. Jain, A.; Samykutty, A.; Jackson, C.; Browning, D.; Bollag, W.B.; Thangaraju, M.; Takahashi, S.; Singh, S.R. Curcumin inhibits PhIP induced cytotoxicity in breast epithelial cells through multiple molecular targets. Cancer Lett. 2015, 365, 122-131. [CrossRef]

51. Liu, Y.; Wu, Y.; Zhang, P. Protective effects of curcumin and quercetin during benzo (a) pyrene induced lung carcinogenesis in mice. Eur. Rev. Med. Pharmacol. Sci. 2015, 19, 1736-1743.

52. CHAN, W.H.; WU, H.J.; HSUUW, Y.D. Curcumin inhibits ROS formation and apoptosis in methylglyoxal-treated human hepatoma G2 cells. Ann. N. Y. Acad. Sci. 2005, 1042, 372-378. [CrossRef]

53. Biswas, J.; Sinha, D.; Mukherjee, S.; Roy, S.; Siddiqi, M.; Roy, M. Curcumin protects DNA damage in a chronically arsenic-exposed population of West Bengal. Hum. Exp. Toxicol. 2010, 29, 513-524. [CrossRef]

54. Liu, Y.; Wu, Y.; Yu, Y.; Cao, C.; Zhang, J.; Li, K.; Zhang, P. Curcumin and resveratrol in combination modulate drug-metabolizing enzymes as well as antioxidant indices during lung carcinogenesis in mice. Hum. Exp. Toxicol. 2015, 34, 620-627. [CrossRef]

55. Duan, W.; Chang, Y.; Li, R.; Xu, Q.; Lei, J.; Yin, C.; Li, T.; Wu, Y.; Ma, Q.; Li, X. Curcumin inhibits hypoxia inducible factor- $1 \alpha$-induced epithelial-mesenchymal transition in HepG2 hepatocellular carcinoma cells. Mol. Med. Rep. 2014, 10, 2505-2510. [CrossRef] 
56. Ghosh, D.; Choudhury, S.T.; Ghosh, S.; Mandal, A.K.; Sarkar, S.; Ghosh, A.; Saha, K.D.; Das, N. Nanocapsulated curcumin: Oral chemopreventive formulation against diethylnitrosamine induced hepatocellular carcinoma in rat. Chem. Biol. Interact. 2012, 195, 206-214. [CrossRef]

57. Iqbal, M.; Sharma, S.D.; Okazaki, Y.; Fujisawa, M.; Okada, S. Dietary supplementation of curcumin enhances antioxidant and phase II metabolizing enzymes in ddY male mice: Possible role in protection against chemical carcinogenesis and toxicity. Pharmacol. Toxicol. 2003, 92, 33-38. [CrossRef]

58. Piper, J.T.; Singhal, S.S.; Salameh, M.S.; Torman, R.T.; Awasthi, Y.C.; Awasthi, S. Mechanisms of anticarcinogenic properties of curcumin: The effect of curcumin on glutathione linked detoxification enzymes in rat liver. Int. J. Biochem. Cell Biol. 1998, 30, 445-456. [CrossRef]

59. Balogun, E.; Hoque, M.; Gong, P.; Killeen, E.; Green, C.J.; Foresti, R.; Alam, J.; Motterlini, R. Curcumin activates the haem oxygenase- 1 gene via regulation of $\mathrm{Nrf} 2$ and the antioxidant-responsive element. Biochem. J. 2003, 371, 887-895. [CrossRef]

60. Motterlini, R.; Foresti, R.; Bassi, R.; Green, C.J. Curcumin, an antioxidant and anti-inflammatory agent, induces heme oxygenase- 1 and protects endothelial cells against oxidative stress. Free Radic. Biol. Med. 2000, 28, 1303-1312. [CrossRef]

61. Sahin, K.; Orhan, C.; Tuzcu, M.; Sahin, N.; Tastan, H.; Özercan, İ.H.; Güler, O.; Kahraman, N.; Kucuk, O.; Ozpolat, B. Chemopreventive and antitumor efficacy of curcumin in a spontaneously developing hen ovarian cancer model. Cancer Prev. Res. 2018, 11, 59-67. [CrossRef] [PubMed]

62. González-Reyes, S.; Guzmán-Beltrán, S.; Medina-Campos, O.N.; Pedraza-Chaverri, J. Curcumin pretreatment induces Nrf2 and an antioxidant response and prevents hemin-induced toxicity in primary cultures of cerebellar granule neurons of rats. Oxid. Med. Cell. Longev. 2013, 2013. [CrossRef] [PubMed]

63. Elmansi, A.M.; El-Karef, A.A.; El-Shishtawy, M.M.; Eissa, L.A. Hepatoprotective effect of curcumin on hepatocellular carcinoma through autophagic and apoptic pathways. Ann. Hepatol. 2017, 16, 607-618. [CrossRef]

64. Sheu, M.-T.; Jhan, H.-J.; Hsieh, C.-M.; Wang, C.-J.; Ho, H.-O. Efficacy of antioxidants as a complementary and alternative medicine (CAM) in combination with the chemotherapeutic agent doxorubicin. Integr. Cancer Ther. 2015, 14, 184-195. [CrossRef]

65. Sreepriya, M.; Bali, G. Effects of administration of Embelin and Curcumin on lipid peroxidation, hepatic glutathione antioxidant defense and hematopoietic system during N-nitrosodiethylamine/Phenobarbital-induced hepatocarcinogenesis in Wistar rats. Mol. Cell. Biochem. 2006, 284, 49-55. [CrossRef]

66. Zhang, Y.; Gordon, G.B. A strategy for cancer prevention: Stimulation of the Nrf2-ARE signaling pathway. Mol. Cancer Ther. 2004, 3, 885-893.

67. Qutub, A.A.; Popel, A.S. Reactive oxygen species regulate hypoxia-inducible factor $1 \alpha$ differentially in cancer and ischemia. Mol. Cell. Biol. 2008, 28, 5106-5119. [CrossRef]

68. Zhao, T.; Zhu, Y.; Morinibu, A.; Kobayashi, M.; Shinomiya, K.; Itasaka, S.; Yoshimura, M.; Guo, G.; Hiraoka, M.; Harada, H. HIF-1-mediated metabolic reprogramming reduces ROS levels and facilitates the metastatic colonization of cancers in lungs. Sci. Rep. 2014, 4, 3793. [CrossRef]

69. Chang, Y.; Jiang, M.; Liu, K.; Li, X. Curcumin inhibited hypoxia induced epithelial-mesenchymal transition in hepatic carcinoma cell line HepG2 in vitro. Zhongguo Zhong Xi Yi Jie He Za Zhi Zhongguo Zhongxiyi Jiehe Zazhi Chin. J. Integr. Tradit. West. Med. 2013, 33, 1102-1106.

70. El-Kenawi, A.; Ruffell, B. Inflammation, ROS, and mutagenesis. Cancer Cell 2017, 32, 727-729. [CrossRef]

71. Agita, A.; Alsagaff, M.T. Inflammation, immunity, and hypertension. Acta Med. Indones 2017, 49, $158-165$.

72. Mittal, M.; Siddiqui, M.R.; Tran, K.; Reddy, S.P.; Malik, A.B. Reactive oxygen species in inflammation and tissue injury. Antioxid. Redox Signal. 2014, 20, 1126-1167. [CrossRef]

73. Sprague, A.H.; Khalil, R.A. Inflammatory cytokines in vascular dysfunction and vascular disease. Biochem. Pharmacol. 2009, 78, 539-552. [CrossRef]

74. Yan, Y.; Li, J.; Ouyang, W.; Ma, Q.; Hu, Y.; Zhang, D.; Ding, J.; Qu, Q.; Subbaramaiah, K.; Huang, C. NFAT3 is specifically required for TNF- $\alpha$-induced cyclooxygenase-2 (COX-2) expression and transformation of Cl41 cells. J. Cell Sci. 2006, 119, 2985-2994. [CrossRef]

75. He, Y.; Xiao, Y.; Yang, X.; Li, Y.; Wang, B.; Yao, F.; Shang, C.; Jin, Z.; Wang, W.; Lin, R. SIRT6 inhibits TNF- $\alpha$-induced inflammation of vascular adventitial fibroblasts through ROS and Akt signaling pathway. Exp. Cell Res. 2017, 357, 88-97. [CrossRef] 
76. Lee, I.-T.; Lin, C.-C.; Lee, C.-Y.; Hsieh, P.-W.; Yang, C.-M. Protective effects of (-)-epigallocatechin-3-gallate against TNF- $\alpha$-induced lung inflammation via ROS-dependent ICAM-1 inhibition. J. Nutr. Biochem. 2013, 24, 124-136. [CrossRef]

77. Murakami, A.; Furukawa, I.; Miyamoto, S.; Tanaka, T.; Ohigashi, H. Curcumin combined with turmerones, essential oil components of turmeric, abolishes inflammation-associated mouse colon carcinogenesis. Biofactors 2013, 39, 221-232. [CrossRef]

78. Prakobwong, S.; Khoontawad, J.; Yongvanit, P.; Pairojkul, C.; Hiraku, Y.; Sithithaworn, P.; Pinlaor, P.; Aggarwal, B.B.; Pinlaor, S. Curcumin decreases cholangiocarcinogenesis in hamsters by suppressing inflammation-mediated molecular events related to multistep carcinogenesis. Int. J. Cancer 2011, 129, 88-100. [CrossRef]

79. Chan, M.M.-Y.; Huang, H.-I.; Fenton, M.R.; Fong, D. In vivo inhibition of nitric oxide synthase gene expression by curcumin, a cancer preventive natural product with anti-inflammatory properties. Biochem. Pharmacol. 1998, 55, 1955-1962. [CrossRef]

80. Youssef, K.M.; El-Sherbeny, M.A.; El-Shafie, F.S.; Farag, H.A.; Al-Deeb, O.A.; Awadalla, S.A.A. Synthesis of curcumin analogues as potential antioxidant, cancer chemopreventive agents. Arch. Pharm. Int. J. Pharm. Med. Chem. 2004, 337, 42-54. [CrossRef]

81. Simon, E.; Aswini, P.; Sameer Kumar, V.; Mankadath, G. Curcumin and its synthetic analogue dimethoxycurcumin differentially modulates antioxidant status of normal human peripheral blood mononuclear cells. Free Radic. Res. 2018, 52, 583-591. [CrossRef]

82. Tu, Z.-S.; Wang, Q.; Sun, D.-D.; Dai, F.; Zhou, B. Design, synthesis, and evaluation of curcumin derivatives as Nrf2 activators and cytoprotectors against oxidative death. Eur. J. Med. Chem. 2017, 134, 72-85. [CrossRef]

83. Liu, D.; He, B.; Lin, L.; Malhotra, A.; Yuan, N. Potential of curcumin and resveratrol as biochemical and biophysical modulators during lung cancer in rats. Drug Chem. Toxicol. 2019, 42, 328-334. [CrossRef]

84. Malhotra, A.; Nair, P.; Dhawan, D. Premature mitochondrial senescence and related ultrastructural changes during lung carcinogenesis modulation by curcumin and resveratrol. Ultrastruct. Pathol. 2012, 36, 179-184. [CrossRef] [PubMed]

85. Malhotra, A.; Nair, P.; Dhawan, D. Modulatory effects of curcumin and resveratrol on lung carcinogenesis in mice. Phytother. Res. 2010, 24, 1271-1277. [CrossRef]

86. Giordano, A.; Tommonaro, G. Curcumin and cancer. Nutrients 2019, 11, 2376. [CrossRef]

87. Gupta, S.C.; Prasad, S.; Kim, J.H.; Patchva, S.; Webb, L.J.; Priyadarsini, I.K.; Aggarwal, B.B. Multitargeting by curcumin as revealed by molecular interaction studies. Nat. Prod. Rep. 2011, 28, 1937-1955. [CrossRef]

88. Morin, D.; Barthélémy, S.; Zini, R.; Labidalle, S.; Tillement, J.-P. Curcumin induces the mitochondrial permeability transition pore mediated by membrane protein thiol oxidation. FEBS Lett. 2001, 495, 131-136. [CrossRef]

89. Watson, J.L.; Hill, R.; Yaffe, P.B.; Greenshields, A.; Walsh, M.; Lee, P.W.; Giacomantonio, C.A.; Hoskin, D.W. Curcumin causes superoxide anion production and p53-independent apoptosis in human colon cancer cells. Cancer Lett. 2010, 297, 1-8. [CrossRef]

90. Thayyullathil, F.; Chathoth, S.; Hago, A.; Patel, M.; Galadari, S. Rapid reactive oxygen species (ROS) generation induced by curcumin leads to caspase-dependent and-independent apoptosis in L929 cells. Free Radic. Biol. Med. 2008, 45, 1403-1412. [CrossRef] [PubMed]

91. Wang, L.; Chen, X.; Du, Z.; Li, G.; Chen, M.; Chen, X.; Liang, G.; Chen, T. Curcumin suppresses gastric tumor cell growth via ROS-mediated DNA polymerase $\gamma$ depletion disrupting cellular bioenergetics. J. Exp. Clin. Cancer Res. 2017, 36, 1-14. [CrossRef] [PubMed]

92. Wang, C.; Song, X.; Shang, M.; Zou, W.; Zhang, M.; Wei, H.; Shao, H. Curcumin exerts cytotoxicity dependent on reactive oxygen species accumulation in non-small-cell lung cancer cells. Future Oncol. 2019, 15, 1243-1253. [CrossRef] [PubMed]

93. Mutlu Altundă̆, E.; Yılmaz, A.M.; Koçtürk, S.; Taga, Y.; Yalçın, A.S. Synergistic induction of apoptosis by quercetin and curcumin in chronic myeloid leukemia (K562) cells. Nutr. Cancer 2018, 70, 97-108. [CrossRef] [PubMed]

94. Liao, W.; Xiang, W.; Wang, F.-F.; Wang, R.; Ding, Y. Curcumin inhibited growth of human melanoma A375 cells via inciting oxidative stress. Biomed. Pharmacother. 2017, 95, 1177-1186. [CrossRef] [PubMed] 
95. Liang, T.; Zhang, X.; Xue, W.; Zhao, S.; Zhang, X.; Pei, J. Curcumin induced human gastric cancer BGC-823 cells apoptosis by ROS-mediated ASK1-MKK4-JNK stress signaling pathway. Int. J. Mol. Sci. 2014, 15, 15754-15765. [CrossRef] [PubMed]

96. Kizhakkayil, J.; Thayyullathil, F.; Chathoth, S.; Hago, A.; Patel, M.; Galadari, S. Glutathione regulates caspase-dependent ceramide production and curcumin-induced apoptosis in human leukemic cells. Free Radic. Biol. Med. 2012, 52, 1854-1864. [CrossRef]

97. Syng-ai, C.; Kumari, A.L.; Khar, A. Effect of curcumin on normal and tumor cells: Role of glutathione and bcl-2. Mol. Cancer Ther. 2004, 3, 1101-1108.

98. Berrak, Ö.; Akkoç, Y.; Arısan, E.D.; Çoker-Gürkan, A.; Obakan-Yerlikaya, P.; Palavan-Ünsal, N. The inhibition of PI3K and NFKB promoted curcumin-induced cell cycle arrest at G2/M via altering polyamine metabolism in Bcl-2 overexpressing MCF-7 breast cancer cells. Biomed. Pharmacother. 2016, 77, 150-160. [CrossRef]

99. Agarwal, A.; Kasinathan, A.; Ganesan, R.; Balasubramanian, A.; Bhaskaran, J.; Suresh, S.; Srinivasan, R.; Aravind, K.; Sivalingam, N. Curcumin induces apoptosis and cell cycle arrest via the activation of reactive oxygen species-independent mitochondrial apoptotic pathway in Smad4 and p53 mutated colon adenocarcinoma HT29 cells. Nutr. Res. 2018, 51, 67-81. [CrossRef]

100. Lestari, B.; Nakamae, I.; Yoneda-Kato, N.; Morimoto, T.; Kanaya, S.; Yokoyama, T.; Shionyu, M.; Shirai, T.; Meiyanto, E.; Kato, J.-y. Pentagamavunon-1 (PGV-1) inhibits ROS metabolic enzymes and suppresses tumor cell growth by inducing M phase (prometaphase) arrest and cell senescence. Sci. Rep. 2019, 9, 1-12. [CrossRef]

101. Luo, C.; Li, Y.; Zhou, B.; Yang, L.; Li, H.; Feng, Z.; Li, Y.; Long, J.; Liu, J. A monocarbonyl analogue of curcumin, 1, 5-bis (3-hydroxyphenyl)-1, 4-pentadiene-3-one (Ca 37), exhibits potent growth suppressive activity and enhances the inhibitory effect of curcumin on human prostate cancer cells. Apoptosis 2014, 19, 542-553. [CrossRef] [PubMed]

102. Chen, M.; Zhou, B.; Zhong, P.; Rajamanickam, V.; Dai, X.; Karvannan, K.; Zhou, H.; Zhang, X.; Liang, G. Increased Intracellular Reactive Oxygen Species Mediates the Anti-Cancer Effects of WZ35 via Activating Mitochondrial Apoptosis Pathway in Prostate Cancer Cells. Prostate 2017, 77, 489-504. [CrossRef] [PubMed]

103. Li, Y.; Zhang, L.-P.; Dai, F.; Yan, W.-J.; Wang, H.-B.; Tu, Z.-S.; Zhou, B. Hexamethoxylated monocarbonyl analogues of curcumin cause G2/M cell cycle arrest in NCI-H460 cells via Michael acceptor-dependent redox intervention. J. Agric. Food Chem. 2015, 63, 7731-7742. [CrossRef] [PubMed]

104. Shi, L.; Fei, X.; Wang, Z. Demethoxycurcumin was prior to temozolomide on inhibiting proliferation and induced apoptosis of glioblastoma stem cells. Tumor Biol. 2015, 36, 7107-7119. [CrossRef]

105. Nakamae, I.; Morimoto, T.; Shima, H.; Shionyu, M.; Fujiki, H.; Yoneda-Kato, N.; Yokoyama, T.; Kanaya, S.; Kakiuchi, K.; Shirai, T. Curcumin derivatives verify the essentiality of ROS upregulation in tumor suppression. Molecules 2019, 24, 4067. [CrossRef]

106. Liu, B.; Cui, L.-s.; Zhou, B.; Zhang, L.-l.; Liu, Z.-h.; Zhang, L. Monocarbonyl curcumin analog A2 potently inhibits angiogenesis by inducing ROS-dependent endothelial cell death. Acta Pharmacol. Sin. 2019, 40, 1412-1423. [CrossRef]

107. Guerrero, S.; Inostroza-Riquelme, M.; Contreras-Orellana, P.; Diaz-Garcia, V.; Lara, P.; Vivanco-Palma, A.; Cárdenas, A.; Miranda, V.; Robert, P.; Leyton, L. Curcumin-loaded nanoemulsion: A new safe and effective formulation to prevent tumor reincidence and metastasis. Nanoscale 2018, 10, 22612-22622. [CrossRef]

108. Larasati, Y.A.; Yoneda-Kato, N.; Nakamae, I.; Yokoyama, T.; Meiyanto, E.; Kato, J.-y. Curcumin targets multiple enzymes involved in the ROS metabolic pathway to suppress tumor cell growth. Sci. Rep. 2018, 8, 1-13. [CrossRef]

109. Khan, M.A.; Gahlot, S.; Majumdar, S. Oxidative stress induced by curcumin promotes the death of cutaneous T-cell lymphoma (HuT-78) by disrupting the function of several molecular targets. Mol. Cancer Ther. 2012, 11, 1873-1883. [CrossRef]

110. Lee, Y.J.; Kim, N.-Y.; Suh, Y.-A.; Lee, C. Involvement of ROS in curcumin-induced autophagic cell death. Korean J. Physiol. Pharmacol. 2011, 15, 1-7. [CrossRef]

111. Gersey, Z.C.; Rodriguez, G.A.; Barbarite, E.; Sanchez, A.; Walters, W.M.; Ohaeto, K.C.; Komotar, R.J.; Graham, R.M. Curcumin decreases malignant characteristics of glioblastoma stem cells via induction of reactive oxygen species. BMC Cancer 2017, 17, 1-11. [CrossRef] [PubMed] 
112. Marquardt, J.U.; Gomez-Quiroz, L.; Camacho, L.O.A.; Pinna, F.; Lee, Y.-H.; Kitade, M.; Domínguez, M.P.; Castven, D.; Breuhahn, K.; Conner, E.A. Curcumin effectively inhibits oncogenic NF- $\kappa$ B signaling and restrains stemness features in liver cancer. J. Hepatol. 2015, 63, 661-669. [CrossRef] [PubMed]

113. Tan, B.L.; Norhaizan, M.E. Curcumin combination chemotherapy: The implication and efficacy in cancer. Molecules 2019, 24, 2527. [CrossRef] [PubMed]

114. Cheng, Y.; Zhao, P.; Wu, S.; Yang, T.; Chen, Y.; Zhang, X.; He, C.; Zheng, C.; Li, K.; Ma, X. Cisplatin and curcumin co-loaded nano-liposomes for the treatment of hepatocellular carcinoma. Int. J. Pharm. 2018, 545, 261-273. [CrossRef] [PubMed]

115. Paciello, F.; Fetoni, A.R.; Mezzogori, D.; Rolesi, R.; Di Pino, A.; Paludetti, G.; Grassi, C.; Troiani, D. The dual role of curcumin and ferulic acid in counteracting chemoresistance and cisplatin-induced ototoxicity. Sci. Rep. 2020, 10, 1-17. [CrossRef]

116. Park, B.H.; Lim, J.E.; Jeon, H.G.; Seo, S.I.; Lee, H.M.; Choi, H.Y.; Jeon, S.S.; Jeong, B.C. Curcumin potentiates antitumor activity of cisplatin in bladder cancer cell lines via ROS-mediated activation of ERK1/2. Oncotarget 2016, 7, 63870. [CrossRef]

117. Sankpal, U.T.; Nagaraju, G.P.; Gottipolu, S.R.; Hurtado, M.; Jordan, C.G.; Simecka, J.W.; Shoji, M.; El-Rayes, B.; Basha, R. Combination of tolfenamic acid and curcumin induces colon cancer cell growth inhibition through modulating specific transcription factors and reactive oxygen species. Oncotarget 2016, 7, 3186. [CrossRef]

118. Jung, E.M.; Park, J.-W.; Choi, K.S.; Park, J.-W.; Lee, H.I.; Lee, K.-S.; Kwon, T.K. Curcumin sensitizes tumor necrosis factor-related apoptosis-inducing ligand (TRAIL)-mediated apoptosis through CHOP-independent DR5 upregulation. Carcinogenesis 2006, 27, 2008-2017. [CrossRef]

119. Chatterjee, S.J.; Pandey, S. Chemo-resistant melanoma sensitized by tamoxifen to low dose curcumin treatment through induction of apoptosis and autophagy. Cancer Biol. Ther. 2011, 11, 216-228. [CrossRef]

120. Huang, Y.-F.; Zhu, D.-J.; Chen, X.-W.; Chen, Q.-K.; Luo, Z.-T.; Liu, C.-C.; Wang, G.-X.; Zhang, W.-J.; Liao, N.-Z. Curcumin enhances the effects of irinotecan on colorectal cancer cells through the generation of reactive oxygen species and activation of the endoplasmic reticulum stress pathway. Oncotarget 2017, 8, 40264. [CrossRef]

121. Chen, T.-C.; Chuang, J.-Y.; Ko, C.-Y.; Kao, T.-J.; Yang, P.-Y.; Yu, C.-H.; Liu, M.-S.; Hu, S.-L.; Tsai, Y.-T.; Chan, H. AR ubiquitination induced by the curcumin analog suppresses growth of temozolomide-resistant glioblastoma through disrupting GPX4-Mediated redox homeostasis. Redox Biol. 2020, 30, 101413. [CrossRef] [PubMed]

122. Moghtaderi, H.; Sepehri, H.; Attari, F. Combination of arabinogalactan and curcumin induces apoptosis in breast cancer cells in vitro and inhibits tumor growth via overexpression of p53 level in vivo. Biomed. Pharmacother. 2017, 88, 582-594. [CrossRef] [PubMed]

123. Mansourizadeh, F.; Alberti, D.; Bitonto, V.; Tripepi, M.; Sepehri, H.; Khoee, S.; Crich, S.G. Efficient synergistic combination effect of Quercetin with Curcumin on breast cancer cell apoptosis through their loading into Apo ferritin cavity. Colloids Surf. B Biointerfaces 2020, 191, 110982. [CrossRef] [PubMed]

124. Du, Q.; Hu, B.; An, H.-M.; Shen, K.-P.; Xu, L.; Deng, S.; Wei, M.-M. Synergistic anticancer effects of curcumin and resveratrol in Hepa1-6 hepatocellular carcinoma cells. Oncol. Rep. 2013, 29, 1851-1858. [CrossRef]

Publisher's Note: MDPI stays neutral with regard to jurisdictional claims in published maps and institutional affiliations.

(C) 2020 by the authors. Licensee MDPI, Basel, Switzerland. This article is an open access article distributed under the terms and conditions of the Creative Commons Attribution (CC BY) license (http://creativecommons.org/licenses/by/4.0/). 